\title{
KEWENANGAN PENGADILAN NIAGA DALAM MEMERIKSA DAN MEMUTUS PERKARA PERMOHONAN PERNYATAN PAILIT
}

(Studi Terhadap Akibat Hukum Kepailitan Berdasarkan Putusan Pengadilan Niaga terhadap Eksekusi atas Harta Kekayaan Debitor Pailit di Pengadilan Negeri)

\author{
Serlika Aprita \\ Fakultas Hukum Universitas Muhammadiyah Palembang \\ JL. Jendral Ahmad Yani 13 Ulu Plaju, Kota Palembang,Sumatera Selatan \\ 5312lika@gmail.com
}

\begin{abstract}
The dualism of the authority to adjudicate between the Commercial Court and the District Court resulted in the emergence of problems regarding jurisdiction to try a case. Problems of power or jurisdiction adjudicate arise due to various factors, one of which is the factor of the judiciary that distinguishes the existence between the appellate court and the court of cassation as a superior court dealing with the inferior court. This type of research in journal writing is normative legal research. In the context of developing the competence or authority of the Commercial Court in the era of globalization, a mature concept is needed to prepare for the expansion of absolute competence of the Commercial Court so that the Commercial Court is credible and credible in the eyes of justice seekers. with the authority of the Commercial Court in examining and deciding the application for bankruptcy statements through the regulation of the specificity of the Commercial Court procedural law.
\end{abstract}

Keywords: Bankruptcy, Commercial Court, District Court, and Bankruptcy

\begin{abstract}
Abstrak, Dualisme kewenangan mengadili antara Pengadilan Niaga dengan Pengadilan Negeri mengakibatkan timbulnya permasalahan mengenai yurisdiksi mengadili suatu perkara. Permasalahan kekuasaan atau yurisdiksi mengadili timbul disebapkan berbagai faktor satu diantaranya faktor instansi peradilan yang membedakan eksistensi antara peradilan banding dan peradilan kasasi sebagai peradilan yang lebih tinggi (superior court) berhadapan dengan peradilan tingkat pertama (inferior court). Jenis penelitian dalam penulisan jurnal ini adalah penelitian hukum normatif. Dalam rangka pengembangan kompetensi atau wewenang Pengadilan Niaga di era globalisasi, maka diperlukan konsep yang matang untuk mempersiapkan perluasan kompetensi absolut dari Pengadilan Niaga agar Pengadilan Niaga dapat dipercaya dan kredibel di mata pencari keadilan, selain itu pula diperlukam pengakuan atas keberadaan dan eksistensi Pengadilan Niaga dalam hubungannya dengan wewenang yang dimiliki Pengadilan Niaga dalam memeriksa dan memutus permohonan pernyataan pailit melalui adanya pengaturan mengenai kekhususan hukum acara Pengadilan Niaga.
\end{abstract}

Kata Kunci: Kepailitan, Pengadilan Niaga, Pengadilan Negeri, dan Pailit.

\section{Pendahuluan}

Dalam kegiatan usaha pada era global seperti sekarang ini pada kenyataannya tidak mungkin terisolir dari masalah-masalah lain. Suatu perusahaan yang dinyatakan pailit pada saat ini akan mempunyai imbas dan pengaruh buruk bukan hanya kepada 
perusahaan itu saja melainkan berakibat global. Pada umumnya krisis moneter yang melanda suatu negara memberi pengaruh yang tidak menguntungkan terhadap kehidupan perekonomian negara yang bersangkutan dan menimbulkan kesulitan besar di kalangan dunia usaha untuk meneruskan kegiatannya. Kemampuan dunia usaha dalam mengembangkan usahanya sangat terganggu, bahkan untuk mempertahankan kelangsungan kegiatan usahanya juga tidak mudah. ${ }^{1}$ Lebih jauh lagi, gejolak tersebut juga telah memberi pengaruh besar terhadap kemampuan dunia usaha untuk memenuhi kewajiban pembayaran utang mereka kepada kreditor. Keadaan ini pada gilirannya telah melahirkan akibat yang berantai dan apabila tidak diselesaikan akan menimbulkan dampak yang lebih luas lagi. Tidak hanya dalam kelangsungan usaha dan segi-segi ekonomi pada umumnya, tetapi juga kepada masalah ketenagakerjaan dan aspek sosial yang perlu diselesaikan dengan adil dalam arti memperhatikan kepentingan pengusaha sebagai debitor ataupun kepentingan kreditor secara seimbang.

Sebagai contoh, ketika Direktur Utama Yamaichi Securities pada tanggal 1 Desember 1995 mengumumkan kebangkrutan perusahaannya pada suatu konfrensi pers di Tokyo,Jepang. Dari kasus ini dapat dilihat banyak pihak yang jadi korban apabila perusahaan dinyatakan pailit. Oleh karena itu lembaga kepailitan merupakan salah satu kebutuhan pokok di dalam aktivitas bisnis karena adanya status pailit. ${ }^{2}$ Untuk mengantisipasi adanya perbuatan-perbuatan debitor yang merugikan kreditor maka, pemerintah melakukan perubahan-perubahan yang cukup signifikan dalam peraturan perundang-undangan, salah satunya adalah dengan merevisi Undang-Undang Kepailitan yang ada. Sebelum Undang-Undang Nomor 4 Tahun 1998 jo Peraturan Pemerintah Pengganti Undang-Undang Nomor 1 Tahun 1998 tentang Penetapan Pemerintah Pengganti Undang-Undang Jo. Peraturan Pemerintah Pengganti Undang-Undang Nomor 1 Tahun 1998 tentang Perubahan Atas Undang-Undang tentang Kepailitan dikeluarkan, masalah Kepailitan dan Penundaan Kewajiban Pembayaran Utang di Indonesia diatur dalam Faillisement Verordening (Staasblad Tahun 1905 Nomor 207 jo. Staatsblad Tahun 1906 Nomor 348).

Dalam perjalanan waktunya Undang-Undang Nomor 4 Tahun 1998 tentang Penetapan Peraturan Pemerintah Pengganti Undang-Undang Kepailitan dirasakan belum mampu mengakomodir semua kepentingan pihak-pihak dalam menyelesaikan masalah utang piutang. Oleh karena itu perlu dibenahi, disempurnakan baik dari aspek formil maupun materielnya. Maka, pada tanggal 18 November 2004 disahkan Undang-Undang Nomor 37 Tahun 2004 tentang Kepailitan dan Penundaan Kewajiban Pembayaran Utang (selanjutnya disebut dengan Kepailitan dan PKPU). ${ }^{3}$ Salah satu persoalan yang sangat mendesak dan memerlukan pemecahan saat ini setelah penyempurnaan aturan kepailitan adalah pembentukan Pengadilan Niaga sebagai pengadilan khusus dalam lingkungan Peradilan Umum. Pengadilan Niaga yang pertama dibentuk adalah Pengadilan Niaga Jakarta Pusat, selanjutnya berdasarkan Keputusan Presiden (Keppres) Nomor 97 Tahun

\footnotetext{
${ }^{1}$ Victorianus M.H. Randa Puang, Penerapan Asas Pembuktian Sederhana dalam Penjatuhan Putusan Pailit, Jakarta: PT.Sarana Tutorial Nurani Sejahtera (SATU NUSA), 2011, hlm.1.

${ }^{2}$ Sri Redjeki Hartini, Hukum Kepailitan, Malang: Universitas Muhamadiyah Malang Press, 2008, hlm.3

${ }^{3}$ Ibid.,hlm.8.
} 
1999 Tentang Pembentukkan Pengadilan Niaga pada Pengadilan Negeri didirikan Pengadilan Niaga di Makassar, Surabaya, Medan, dan Semarang.

Undang-undang memberikan ruang terbentuknya Pengadilan Khusus yang berada di bawah lingkungan Peradilan Umum dengan syarat bahwa pembentukan Pengadilan Khusus tersebut ditetapkan melalui undang-undang. Hal ini berarti menjelaskan bahwa pembentukan Pengadilan Niaga merupakan suatu implementasi dari bentuk Pengadilan Khusus yang berada di bawah lingkungan Peradilan Umum. Secara konvensi teori perundang-undangan, pembentukkan Pengadilan Khusus biasanya dilakukan melalui undang-undang tersendiri yang mengamanatkan pembentukannya tersebut.

Kewenangan Pengadilan Niaga dalam memutuskan permohonan pernyataan pailit mengakibatkan timbulnya suatu akibat hukum yang secara teoritis diatur dalam Bagian Kedua Undang-Undang Kepailitan Nomor 37 Tahun 2004 yang terdiri dari Pasal 19 sampai dengan Pasal 62. ${ }^{4}$ Satu diantaranya adalah akibat hukum kepailitan terhadap eksekusi atas harta kekayaan debitor pailit. Berdasarkan ketentuan Pasal 32 jo Pasal 31 ayat 1 Undang-Undang Kepailitan Nomor 37 Tahun 2004 menyatakan bahwa dengan dikeluarkannya pernyataan pailit maka semua putusan hakim yang telah dijatuhkan sebelum pernyataan pailit dikeluarkan, sepanjang yang menyangkut bagian dari harta pailit harus segera dihentikan pelaksanaannya, dan sejak itu tidak ada suatu putusan yang dapat dilaksanakan termasuk atau juga dengan menyandera debitor. Ketentuan Pasal ini menunjukkan adanya pengaturan mengenai mekanisme untuk menghentikan putusan Pengadilan Negeri yang menetapkan eksekusi atas harta kekayaan debitor pailit melalui Pengadilan Niaga. Berdasarkan ketentuan pasal ini jelaslah bahwa pelaksanaan hukum setidak-tidaknya menyangkut beberapa hal, yaitu: (a) penyitaan; (b) paksaan badan; (c)uang paksa; (d) penjualan barang untuk melunasi utang; (d) pembalikkan nama, hipotik, oogstverband; (e) kelampauan waktu (daluarsa). ${ }^{5}$ Selanjutnya, pada ketentuan Pasal 56 Undang-Undang Kepailitan Nomor 37 Tahun 2004 menyatakan bahwa hak eksekusi kreditor sebagaimana dimaksud pada ketentuan Pasal 55 ayat 1 Undang-Undang Nomor 37 Tahun 2004 dan hak pihak ketiga untuk menuntut hartanya yang berada dalam penguasaan debitor pailit atau kurator ditangguhkan untuk jangka waktu paling lama 90 (sembilan puluh) hari sejak tanggal putusan pernyataan pailit diucapkan. Selama jangka waktu penangguhan tersebut, kurator dapat mempergunakan harta pailit berupa benda tidak bergerak maupun benda bergerak atau menjual harta pailit yang berupa benda bergerak yang berada dalam penguasaan kurator dalam rangka kelangsungan usaha debitor, dalam hal telah diberikan perlindungan wajar bagi kepentingan kreditor atau pihak ketiga.

Kewenangan yang dimiliki oleh Pengadilan Niaga dan Pengadilan Negeri yang mengakibatkan terjadinya dualisme kewenangan dalam proses penyelesaian sengketa antara Pengadilan Niaga dengan Pengadilan Negeri Jakarta Pusat dalam hal pemeriksaan perkara, terutama perkara memeriksa dan memutuskan permohonan pernyataan pailit. Dengan adanya putusan pernyataan pailit kepada debitor, maka secara langsung

${ }^{4}$ Parwoto Wignjosumarto, Hukum Kepailitan Selayang Pandang “ Himpunan Makalah”, (Jakarta: PT. Tata Nusa, 2003), hlm.118.

${ }^{5}$ Zainal Asikin, Hukum Kepailitan dan Penundaan Kewajiban Pembayaran Utang di Indonesia, (Bandung: Pustaka Reka Cipta, 2013), hlm.55. 
mengakibatkan segala bentuk putusan hakim yang telah dijatuhkan sebelum pernyataan pailit dikeluarkan, dinyatakan tidak dapat dilaksanakan. Hal ini menunjukkan adanya suatu bentuk kompetensi yang dimiliki oleh Pengadilan Niaga untuk menghentikan putusan Pengadilan Negeri yang menetapkan eksekusi atas harta kekayaan debitor pailit.

Berbagai fakta hukum menunjukkan adanya kompetensi yang dimiliki oleh Pengadilan Niaga untuk menghentikan putusan Pengadilan Negeri yang menetapkan eksekusi atas harta kekayaan debitor pailit, satu diantaranya seperti pada Kasus Garuda Indonesia Airways. Dimana, Garuda Indonesia Airways sedang menghadapi masalah hukum, maskapai penerbangan nasional ini digugat secara perdata dan dimohonkan pailit ke Pengadilan Niaga. Asosiasi Pilot Garuda (APG) mengajukan gugatan di Pengadilan Negeri Jakarta Pusat. APG menganggap Garuda Indonesia telah melakukan pelanggaran dalam perjanjian kerja bersama. Pada saat yang bersamaan Pengadilan Niaga Jakarta Pusat menyidangkan permohonan pailit terhadap Garuda Indonesia. Permohonan pailit terhadap Garuda Indonesia diajukan oleh PT. Magnus Indonesia dengan alasan Garuda Indonesia belum membayar biaya konsultan. Itu sebabnya Magnus menempuh upaya pailit. Agar sesuai dengan ketentuan Undang-Undang Kepailitan Nomor 37 Tahun 2004 Magnus membeberkan beberapa kreditor lain, seperti Lufthansa dan PT. Multi Bintang Indonesia. ${ }^{6}$

Dengan adanya penghentian pelaksanaan terhadap semua keputusan hakim yang dijatuhi sebelum pernyataan pailit, hal ini akan memberikan suatu ketidakpastian tentang hubungan hukum yang ada antara debitor dengan pihak ketiga atau penggugat yang dimenangkan di Pengadilan Negeri sehubungan dengan adanya putusan Pengadilan Niaga yang menghentikan eksekusi atas harta kekayaan debitor pailit. Bentuk ketidakpastian ini dimana pada satu sisi debitor mempunyai kewajiban terhadap pelunasan piutangnya kepada kreditor di Pengadilan Niaga, sedangkan pada sisi lain debitor juga harus memenuhi prestasi kepada pihak ketiga atau pengugat di Pengadilan Negeri.

Dualisme kewenangan mengadili antara Pengadilan Niaga dengan Pengadilan Negeri mengakibatkan timbulnya permasalahan mengenai yurisdiksi mengadili suatu perkara. Permasalahan kekuasaan atau yurisdiksi mengadili timbul disebapkan berbagai faktor satu diantaranya faktor instansi peradilan yang membedakan eksistensi antara peradilan banding dan peradilan kasasi sebagai peradilan yang lebih tinggi (superior court) berhadapan dengan peradilan tingkat pertama (inferior court). ${ }^{7}$ Tujuan utama untuk membahas yurisdiksi atau kewenangan mengadili perkara permohonan pernyataan pailit antara Pengadilan Niaga dengan Pengadilan Negeri adalah untuk memberikan penjelasan mengenai masalah pengadilan mana yang benar dan tepat berwenang mengadili suatu sengketa yang timbul. Sebab apabila pengajuannya keliru mengakibatkan gugatan dinyatakan tidak dapat diterima atas alasan pengadilan yang dituju tidak berwenang mengadilinya.

${ }^{6}$ Gugatan Perdata dan Kepailitan Mengancam Garuda Indonesia, http:// www. hukumonline.com/berita/baca/hol14292/gugatan-perdata-dan-perkara-kepailitan-yang-mengancam garuda, diakses tanggal 3 Desember 2014.

M. Yahya Harahap, Hukum Acara Perdata Tentang Gugatan, Persidangan, Penyitaan, Pembuktian, dan Putusan Pengadilan, (Jakarta: Sinar Grafika, 2005), hlm.179.

$$
\sim 64 \sim
$$


Berdasarkan latar belakang permasalahan sebagaimana diuraikan diatas maka penulis memandang perlu untuk dilakukan tulisan jurnal yang berjudul "KEWENANGAN PENGADILAN NIAGA DALAM MEMERIKSA DAN MEMUTUS PERKARA PERMOHONAN PERNYATAN PAILIT (Studi Terhadap Akibat Hukum Kepailitan Berdasarkan Putusan Pengadilan Niaga terhadap Eksekusi atas Harta Kekayaan Debitor Pailit di Pengadilan Negeri)".

Adapun rumusan masalah yang akan dikaji dalam tulisan ini yaitu:

1. Bagaimanakah kompetensi Pengadilan Niaga dalam memeriksa dan memutus perkara permohonan pernyataan pailit?

2. Bagaimanakah rasio hukum putusan Pengadilan Niaga menghentikan putusan Pengadilan Negeri yang menetapkan eksekusi atas harta kekayaan debitor pailit?

\section{Metode Penelitian}

Metode penelitian yang digunakan dalam penulisan jurnal ini adalah penelitian hukum normatif. Yang dikenal juga dengan penelitian doctrinal. ${ }^{8}$ yakni penelitian kepustakaan yang mencakup penelitian asas-asas hukum, sistematik hukum, taraf sinkronisasi vertikal dan horizontal untuk memperoleh data sekunder yang mencakapu bahan hukum primer,sekunder, dan bahan hukum tertier. ${ }^{9}$ Penelitian hukum normatif adalah penelitian yang ditujukan untuk mendapatkan hukum yang objektif (norma hukum). ${ }^{10}$ Dengan demikian untuk kedalaman analisis penelitian maka digunakan beberapa pendekatan ${ }^{11}$ yaitu pendekatan perundang-undangan (statute approach), yaitu mengkaji norma-norma yang terdapat dalam ketentuan perundang-undangan, dan dengan pendekatan konseptual (conceptual approach), yaitu mengkaji konsep-konsep yuridis yang berkaitan dengan implementasi peraturan perundang-undangan hukum kepailitan dan penundaan kewajiban pembayaran utang.

\section{Pembahasan}

\section{Kompetensi Pengadilan Niaga dalam Memeriksa dan Memutus Perkara Permohonan Pernyataan Pailit}

Pengaturan mengenai kewenangan Pengadilan Niaga diatur dalam Undang-Undang Nomor 37 Tahun 2004 tentang Kepailitan dan Penundaan Kewajiban Pembayaran Utang, tidak dengan undang-undang tersendiri yang mengatur tentang susunan, kedudukan, kewenangan, dan hukum acara Pengadilan Niaga sebagaimana ditentukan dalam UndangWewenang Pengadilan Niaga merupakan hak, dalam arti kekuasaan yang diberikan oleh undang-undang untuk menjalankan tugas (kewajiban) yang dibebankan. Pengadilan

\footnotetext{
${ }^{8}$ Jonaedi Efendi dan Johny Ibrahim,Metode Penelitian Hukum Normatif dan Empiris, Cetakan Kedua, (Depok:PrenadaMedia Group, 2018), hlm.124.

${ }^{9}$ Soerjono Soekanto dan Sri Mamudji, Penelitian Hukum Suatu Tinjauan Singkat, (Jakarta: PT RajaGrafindo Persada,2001), hlm.14

${ }^{10}$ Hardijan Rusli, Metode Penelitian Hukum Normatif:Bagaimana?, Law Review Fakultas Hukum Universitas Pelita Harapan, Volume Vol No.3 Tahun 2006,hlm.50.

${ }^{11}$ Soerjono Soekanto, Pengantar Penelitian Hukum, Cetakan III, (Jakarta: UI-Press, 2008), hlm 52. 
Niaga merupakan lembaga peradilan yang berada dibawah Peradilan Umum. ${ }^{12}$ Berdasarkan wewenang Pengadilan Niaga dalam memutuskan perkara kepailitan, maka dalam hal ini Pengadilan Negeri kedudukannya membawahi Pengadilan Niaga. ${ }^{13}$

Dalam membahas mengenai kedudukan dan kompetensi yang dimiliki oleh Pengadilan Niaga, kita perlu mengacu kepada Pasal 284 ayat 1 Undang-Undang Nomor 4 Tahun 1998 yang menyatakan bahwa ketentuan hukum acara yang dipergunakan dalam Pengadilan Niaga adalah sama dengan ketentuan hukum acara perdata Het Inlands Reglement (HIR) yang berlaku di IndonesiaUndang Dasar 1945. Hal ini sejalan dengan pendapat Asep Iwan Iriawan yang menyatakan bahwa sengketa bisnis yang diajukan ke Pengadilan Niaga berbagai macam kasus, tapi kewenangan Pengadilan Niaga ini tidak jelas dan tegas disebutkan dalam Undang-Undang Kepailitan. "Undang-undang ini terkadang membuat bingung para hakim, inilah yang membuat ketidakpastian, dalam suatu perkara ada yang membolehkan ada yang tidak membolehkan. ${ }^{14}$

Secara umum wewenang Pengadilan Niaga dapat dilihat pada ketentuan Pasal 281 ayat (1) Peraturan Pemerintah Pengganti Undang-Undang Nomor 1 Tahun 1998 jo Undang-Undang Nomor 4 Tahun 1998 menyatakan bahwa Pengadilan Niaga tetap berwenang memeriksa dan memutus perkara yang menjadi ruang lingkup Pengadilan Niaga sebagaimana dalam bagian Ketentuan Penutup Bab VII Pasal 306 Undang-Undang Kepailitan Nomor 37 Tahun 2004 tentang Kepailitan dan PKPU yang menyatakan bahwa:

"Pengadilan Niaga pada Pengadilan Negeri Jakarta Pusat yang dibentuk berdasarkan ketentuan pasal 281 ayat (1) Peraturan Pemerintah Pengganti Undang-Undang tentang Kepailitan sebagaiman telah ditetapkan menjadi Undang-Undang Nomor 4 Tahun 1998, dinyatakan tetap berwenang memeriksa dan memutus perkara yang menjadi lingkup tugas Pengadilan Niaga”.

Pasal 300 ayat (1) Undang-Undang Kepailitan Nomor 37 Tahun 2004 tentang Kepailitan dan PKPU yang menyatakan bahwa "Pengadilan sebagaimana dimaksud dalam Undang-Undang ini, selain memeriksa dan memutus permohonan pernyataan pailit dan Penundaan Kewajiban Pembayaran Utang, berwenang pula memeriksa dan memutus perkara lain di bidang perniagaan yang penetapannya dilakukan oleh UndangUndang".

Berdasarkan Keputusan Presiden Nomor 97 Tahun 1999, pemerintah membentuk Pengadilan Niaga pada empat wilayah Pengadilan Negeri lainnya, yaitu sebagai berikut :

1. Pengadilan Negeri Ujung Pandang

2. Pengadilan Negeri Medan

3. Pengadilan Negeri Surabaya

4. Pengadilan Negeri Semarang

12 Rahayu Hartini, Hukum Kepailitan, (Malang: Universitas Muhamadiyah Malang, 2008), hlm 258.

${ }^{13}$ Kewenangan Pengadilan Niaga dalam Mengadili Perkara Kepailitan, http:/ www. Journalonlines .Info/, diakases pada 3 Desember 2014.

${ }^{14}$ Asep Iwan Iriawan, Kewenangan Pengadilan Niaga Tidak Jelas, http: //www. Maxblogpress. com/plugins/ msa/, Berita, diakses pada 7 Desember 2014. 
Dengan pembagian kewenangan tersebut, kewenangan Pengadilan Niaga pada Pengadilan Negeri Jakarta Pusat hanya terbatas pada daerah hukumnya. Untuk mengatasi masa peralihan kewenangan antara Pengadilan Niaga dengan Pengadilan Negeri Jakarta Pusat dengan Pengadilan Niaga pada Pengadilan Negeri lainnya, dalam Pasal 4 Keputusan Presiden Nomor 97 Tahun 1999 ditentukan sebagai berikut:

1. Sengketa di bidang perniagaan yang termasuk ruang lingkup kewenangan Pengadilan Niaga pada Pengadilan-Pengadilan Negeri sebagaimana dimaksud pada ketentuan Pasal 1 Keputusan Presiden Nomor 97 Tahun 1999 pada saat keputusan Presiden ini ditetapkan telah diperiksa, tetapi belum diputus oleh Pengadilan Niaga pada Pengadilan Negeri Jakarta Pusat.

2. Sengketa di bidang perniagaan yang termasuk lingkup kewenangan Pengadilan Niaga pada Pengadilan-Pengadilan Negeri sebagaimana dimaksud pada Pasal 1 pada saat Keputusan Presiden ditetapkan telah diajukan tetapi belum diperiksa oleh Pengadilan Niaga pada Pengadilan Negeri Jakarta Pusat, dilimpahkan kepada Pengadilan Niaga pada Pengadilan Negeri Ujung Pandang, Pengadilan Negeri Medan, Pengadilan Negeri Surabaya, dan Pengadilan Negeri Semarang sebagaimana dimaksud pada ketentuan Pasal 2 Keputusan Presiden Nomor 97 Tahun $1999 .{ }^{15}$

Wewenang Pengadilan Niaga dalam kaitannya dengan tugas pokoknya terbagi atas 2 bentuk yaitu sebagai berikut:

1. Kewenangan absolut

Berarti Pengadilan Niaga berwenang memeriksa setiap permohonan pernyataan pailit dan PKPU serta berwenang untuk memeriksa perkara lain yang ditetapkan dengan undang-undang. Setidaknya ada lima bidang dominan yang ingin diperluas kewenangan absolut Pengadilan Niaga, yaitu sebagai berikut:

1. Perbankan

Bank sangat terkait dengan kepentingan masyarakat. Masalah hukum perbankan tidak sesederhana sebagaimana persyaratan pailit dan membutuhkan pembuktian yang tidak sumir. Putusan di tingkat Pengadilan Niaga sampai Mahkamah Agung kenyataannnya telah memutuskan pengertian utang pada beberapa definisi. ${ }^{16} \mathrm{Hal}$ ini dikarenakan Undang-Undang Kepailitan tidak tegas mendefinisikan utang sehingga dalam praktek berkembang dua macam pertimbangan hakim.

2. Asuransi

Lembaga penyelesaian sengketa niaga untuk bidang asuransi sangat dibutuhkan, mengingat para pencari keadilan menganggap Pengadilan Niaga sebagai lembaga penyelesaian yang murah, cepat, dan mudah.

3. Pasar Modal

Saat ini ada Badan Arbitrase Pasar Modal Indonesia (BAPMI) yang menyediakan sarana alternatif penyelesaian sengketa di bidang pasar modal yang cepat, transparan, mandiri dan adil.

4. Perseroan

15 Jono, Hukum Kepailitan, (Jakarta: Sinar Grafika, 2008), hlm. 84.

${ }^{16}$ H.P.Panggabean, "Tanggapan Terhadap Persepsi Negatif Masyarakat Mengenai Pengadilan Niaga dan Putusan-Putusannya”, Jurnal Hukum Bisnis Vol 2 No.4, 2003, hlm.43-60. 


\section{HAKI}

Kewenangan absolut tersebut juga diperluas dengan menambahkan kewenangan pemeriksaan sengketa pada merek dan paten. Adapun bidang-bidang yang dapat ditangani oleh Pengadilan Niaga antara lain Desain Industri dan Tata Letak Sirkuit Terpadu.

Selain itu, Undang-Undang Kepailitan juga mempertegas kewenangan Pengadilan Niaga yang terkait dengan perjanjian yang memuat klausula arbitrase, yaitu pada ketentuan Pasal 303 Undang-Undang Kepailitan Nomor 37 Tahun 2004 yang menyatakan bahwa :

"Pengadilan tetap berwenang memeriksa dan menyelesaikan permohonan pernyataan pailit dari para pihak yang terikat dengan perjanjian yang memuat klausula arbitrase, sepanjang utang yang menjadi dasar permohonan pernyaatan pailit telah memenuhi ketentuan sebagaimana dimaksud pada Pasal 2 ayat (1) undang-undang ini”.

Pasal 303 Undang-Undang Kepailitan Nomor 37 Tahun 2004 memberikan penegasan bahwa meskipun dalam perjanjian utang piutang mengandung klausula arbitrase, Pengadilan Niaga tetap berwenang untuk memeriksa dengan syarat bahwa utang yang menjadi dasar permohonan pernyataan pailit telah memenuhi ketentuan yaitu adanya dua atau lebih kreditor dan tidak membayar lunas sedikitnya satu utang yang telah jatuh waktu dan dapat ditagih.

Di samping itu, terdapat beberapa argumentasi yuridis mengenai kewenangan absolut yang ekslusif dalam persoalan kepailitan, yaitu sebagai berikut:

1. Bahwa Undang-Undang Kepailitan merupakan lex specialis dari Undang-Undang Arbitrase. Dalam Undang-Undang Kepailitan secara tegas dinyatakan bahwa Pengadilan Niaga merupakan satu-satunya pengadilan yang berwenang untuk memeriksa dan memutus perkara kepailitan dan PKPU. Ketentuan ini merupakan ketentuan yang memaksa (aanvullenrechts) dan tidak dapat dikesampingkan oleh para pihak dengan mencantumkan klasula arbitrase.

2. Bahwa undang-undang juga tidak memberikan pilihan hukum dalam permohonan kepailitan selain daripada kewenangan Pengadilan Niaga sebagai pengadilan khusus, dan tentang kewenangan mengadili kepailitan tersebut, Pengadilan Niaga tidak tunduk pada pilihan hukum dan kewenangan yang diatur dalam perjanjian. ${ }^{17}$

Adapun Sengketa Niaga yang termasuk kompetensi absolut Pengadilan Niaga dapat diartikan sebagai:

1. Sengketa yang tidak termasuk kompetensi absolut Pengadilan Negeri, Peradilan Agama, Peradilan Militer, Peradilan Tata Usaha Negara, Peradilan Anak-anak, Badan Urusan Piutang dan Lelang Negara (BUPLN);

2. Sengketa antara orang-orang yang beragama Islam, mengenai nikah, talak, rujuk, perceraian, perwalian, warisan, wakaf;

${ }^{17}$ M. Hadi Subhan, Hukum Kepailitan "Prinsip, Norma dan Praktik di Peradilan", (Jakarta: Kencana, 2008), hlm.343. 
3. Sengketa mengenai status perorangan termasuk warisan yang diatur dalam KUHPerdata;

4. Sengketa yang berhubungan dengan perjanjian dimana para pihak telah membuat perjanjian arbitrase tertulis yaitu para pihak telah membuat kesepakatan tentang cara penyelesaian sengketa perdata di luar peradilan umum. Menurut ketentuan Pasal 3 Undang-Undang Nomor 30 Tahun 1999 tentang Arbitrase dan Alternatif Penyelesaian Sengketa menyatakan bahwa Pengadilan Negeri tidak berwenang untuk mengadili sengketa para pihak yang telah terikat dalam perjanjian atbitrase. Namun, ketentuan Pasal 3 Undang-Undang Nomor 30 Tahun 1999 Tentang Arbitrase dan Alternatif Penyelesaian Sengketa tidak sinkron dengan UndangUndang Kepailitan yang justru berwenang memeriksa dan menyelesaikan permohonan pernyataan pailit dari para pihak yang terikat perjanjian yang memuat klausula arbitrase. ${ }^{18}$

Problematika lebih lanjut dari kewenangan absolut Pengadilan Niaga dalam sengketa kepailitan adalah apakah kompetensi absolut tersebut hanya memeriksa, mengadili, dan memutus perkara permohonan pailit dan Penundaan Kewajiban Pembayaran Utang (PKPU). Artinya, bagaimana dengan perkara-perkara yang berkaitan dengan kepailitan, misalnya actio pauliana kepailitan, sengketa perburuhan dalam perseroan terbatas yang pailit, bantahan terhadap sita jaminan atas harta kekayaan debitor sebelum dinyatakan pailit.

Dalam ketentuan Pasal 3 ayat 1 Undang-Undang Kepailitan Nomor 37 Tahun 2004 menyatakan bahwa "Putusan atas permohonan pernyataan pailit dan hal-hal lain yang berkaitan dan/atau diatur dalam dalam undang-undang ini diputuskan oleh pengadilan yang daerah hukumnya meliputi daerah tempat kedudukan hukum debitor". Adapun yang dimaksudkan hal-hal yang lain, adalah antara lain, actio pauliana, perlawanan pihak ketiga terhadap penyitaan, atau perkara dimana debitor, kreditor, kurator atau pengurus menjadi salah satu pihak dalam perkara yang berkaitan dengan harta pailit termasuk gugatan kurator terhadap direksi yang menyebapkan perseroan dinyatakan pailit karena kelalaiannya atau kesalahannya. Hukum acara yang berlaku dalam mengadili perkara termasuk "hal-hal lain" adalah sama dengan Hukum Acara Perdata yang berlaku bagi perkara permohonan pernyataan pailit termasuk mengenai pembatasan jangka waktu penyelesaiannya. ${ }^{19}$

\section{Kewenangan relatif}

Kompetensi relatif merupakan kewenangan atau kekuasaan mengadili antar Pengadilan Niaga. Pengadilan Niaga sampai saat ini baru ada lima. Hal ini ditunjukkan dengan adanya pembagaian wilayah yurisdiksi relatif bagi perkara yang diajukan kepada Pengadilan Niaga berdasarkan Keputusan Presiden Nomor 97 Tahun 1999 yaitu sebagai berikut:

\footnotetext{
18 Annalisa Yahanan, Hukum Kepailitan dan Penundaan Kewajiban Pembayaran Utang, (Palembang: UNSRI, 2007), hlm.19.

${ }^{19}$ M. Hadi Subhan, Op.Cit., hlm.103-104. 
a. Daerah hukum Pengadilan Niaga pada Pengadilan Negeri Ujung Pandang meliputi wilayah Provinsi Sulawesi Selatan, Sulawesi Tenggara, Sulawesi Tengah, Sulawesi Utara, Maluku, dan Irian Jaya;

b. Daerah hukum Pengadilan Niaga pada Pengadilan Negeri Medan meliputi provinsi Sumatera Utara, Riau, Sumatera Barat, Jambi, Bengkulu, dan Daerah Istimewa Aceh;

c. Daerah hukum Pengadilan Niaga pada Pengadilan Negeri Surabaya meliputi provinsi Jawa Timur, Kalimantan Selatan, Kalimantan Tengah, Kalimantan Timur, Bali, Nusa Tenggara Barat, Nusa Tenggara Timur, dan Timor Timur;

d. Daerah hukum Pengadilan Niaga pada Pengadilan Negeri Semarang, meliputi provinsi Jawa Tengah dan Daerah Istimewa Yogyakarta.

Adanya dualisme kewenangan dalam hal mengadili antara Pengadilan Negeri dan Pengadilan Niaga berkaitan erat dengan fokus kajian teori kewenangan ialah berkaitan dengan sumber kewenangan dari pemerintah dalam melakukan perbuatan hukum, baik dalam hubungannya dengan hukum publik maupun dalam hubungannya dengan hukum privat. Indroharto mengemukakan tiga macam kewenangan yang bersumber dari peraturan perundang-undangan. Kewenangan itu meliputi: (a) Atribusi merupakan pemberian kewenangan oleh pembuat undang-undang sendiri kepada suatu organ pemerintahan, baik yang sudah ada maupun yang baru sama sekali; (b) Delegasi merupakan penyerahan wewenang yang dipunyai oleh organ pemerintahan kepada organ lain; (c) Mandat merupakan pelimpahan wewenang kepada bawahan. ${ }^{20}$

Pengadilan Niaga diharapakan mampu memberikan solusi penyelesaian sengketa utang piutang yang terjadi antara debitor dan kreditor, sehingga perlindungan hukum yang seimbang bagi para pihak dapat tercapai sehingga akan berkesesuaian dengan keberlakuan asas keseimbangan yang diatur dalam Penjelasan Umum Undang-Undang Nomor 37 Tahun 2004 tentang Kepailitan dan PKPU. Keberadaan Pengadilan Niaga dalam era globalisasi ini sangat diperlukan untuk menyelesaikan sengketa-sengketa niaga secara cepat, selain itu juga Pengadilan Niaga berwenang menyelesaikan aneka masalah kepailitan, seperti masalah pembuktian, verifikasi utang, actio pauliana, dan lain sebagainya.

Permasalahan lain yang muncul adalah berkaitan dengan penyelesaian perkara kepailitan adalah tentang kewenangan Pengadilan, yaitu antara Pengadilan Niaga dan Pengadilan Negeri. Pengadilan Niaga berada pada lingkungan Peradilan Umum dalam hal ini adalah Pengadilan Negeri. Namun demikian, kewenangannya berbeda dengan Pengadilan Negeri. Berdasarkan ketentuan Pasal 50 Undang-Undang Nomor 2 Tahun 1986 tentang Peradilan Umum menyatakan bahwa Pengadilan Negeri bertugas dan berwenang memeriksa, memutus, dan menyelesaikan perkara perdata dan pidana di tingkat pertama. Perubahan secara umum atas Undang-Undang Nomor 2 Tahun 1986 tentang Peradilan Umum sebagaimana yang telah diubah dengan Undang-Undang Nomor 8 Tahun 2004 tentang Peradilan Umum pada dasarnya untuk peradilan yang bersih serta berwibawa, yang dilakukan melalui penataan sistem peradilan yang terpadu (integrated

${ }^{20}$ Salim HS dan Erlies Septiana Nurbani, Penerapan Teori Hukum Pada Penelitian Tesis dan Disertasi, (Jakarta: PT. RajaGrafindo Persada, 2013), hlm.196.

$$
\sim 70 \sim
$$


justice system), terlebih peradilan umum secara konstitusional merupakan salah satu badan peradilan di bawah Mahkamah Agung yang mempunyai kewenangan dalam memeriksa, mengadili dan memutus perkara perdata dan pidana. Kemudian pada ketentuan Pasal 1 angka 1 Undang-Undang Nomor 49 Tahun 2009 tentang Perubahan Kedua Atas Undang-Undang Nomor 2 Tahun 1986 tentang Peradilan Umum menyatakan Pengadilan adalah Pengadilan Negeri dan Pengadilan Tinggi di lingkungan Peradilan Umum.

Dalam pelaksanaan tugas kewenangan tersebut, ternyata pada dasarnya proses kepailitan di Pengadilan tidak efektif. Hal ini terjadi, karena sering terdapat perkaraperkara yang menimbulkan persinggungan antara Pengadilan Negeri dan Pengadilan Niaga, Adapun persinggungan yang terjadi adalah sebagai berikut:

1. Berdasarkan ketentuan Pasal 22 Undang-Undang Kepailitan Nomor 37 Tahun 2004 menjelaskan bahwa demi hukum debitor paiit kehilangan haknya untuk berbuat bebas atas harta kekayaannya, sehinggga karena itu ia tidak berhak bertindak sebagai penggugat atau tergugat.

2. Berdasarkan ketentuan Pasal 24 Undang-Undang Kepailitan Nomor 37 Tahun 2004 menyatakan bahwa debitor pailit yang hendak menuntut haknya (dalam hal ini sebagai penggugat) atau yang dituntut memenuhi kewajibannya (dalam hal ini sebagai tergugat), harus diwakili oleh kurator.

3. Berdasarkan ketentuan Pasal 25 Undang-Undang Nomor 37 Tahun 2004 menyatakan bahwa bagi pihak yang mempunyai tagihan kepada debitor pailit, haknya hanyalah memajukan dan melaporkan kepada kurator untuk dicocokkan.

4. Berdasarkan ketentuan Pasal 26 Undang-Undang Kepailitan Nomor 37 Tahun 2004 menyatakan bahwa apabila ada tuntutan dari debitor pailit terhadap tergugat, maka atas permintaan tergugat, perkara harus ditangguhkan untuk keperluan hakim memanggil kurator agar mengambil alih perkara.

5. Berdasarkan ketentuan Pasal 32 ayat 1 Undang-Undang Nomor 37 Tahun 2004 menyatakan bahwa segala pelaksanaan putusan hakim terhadap setiap bagian harta kekayaan si berutang (debitor pailit) yang telah dimulainya sebelum kepailitan, harus seketika dihentikan. ${ }^{21}$

Dalam rangka mempersiapkan sebuah institusi Pengadilan Niaga yang lebih baik di Indonesia, maka beberapa kewenangan Pengadilan Negeri khususnya perkara yang memiliki tingkat kerumitan cukup tinggi yang dapat dialihkan dapat dialihkan ke Pengadilan Niaga secara bertahap, sehingga hal ini dapat mengurangi beban Pengadilan Umum. Yang perlu dipersiapkan tatkala kewenangan perkara dari Pengadilan Umum dilimpahkan kepada Pengadilan Niaga yaitu perkara yang dilimpahkan sesuai dengan karakteristik Pengadilan Niaga yaitu prosenya cepat dan prosedur pembuktiannya sederhana. Hal ini merupakan satu kesatuan. Sebab tidak mungkin dilaksanakan prosesnya cepat jika tetap mengacu pada hukum acara yang berlaku di Pengadilan Negeri. Konsekuensi logisnya adalah perkara yang dilimpahkan harus disederhanakan baik dalam konteks prosedural maupun pembuktiannya.

Dalam kaitannya dengan kompetensi yang dimiliki oleh Pengadilan Niaga untuk menghentikan putusan Pengadilan Negeri yang menetapkan eksekusi atas harta kekayaan

${ }^{21}$ Parwoto Wignjosumarto, Hukum Kepailitan Selayang Pandang "Himpunan Makalah", (Jakarta: PT. TataNusa), hlm.134. 
debitor pailit, terlebih dahulu perlu diketahui kompetensi yang dimiliki oleh Pengadilan Negeri yang merupakan wewenang Pengadilan Negeri dalam menyelenggarakan kekuasaan kehakiman untuk menerima, memeriksa, dan mengadili serta menyelesaikan setiap perkara yang diajukan kepadanya. Pengadilan Negeri merupakan pengadilan sehari-hari biasa untuk segala penduduk, yang mempunyai wewenang untuk memeriksa dan memutus dalam peradilan tingkat pertama segala perkara perdata dan pidana yang dulu diperiksa dan diputus oleh pengadilan-pengadilan yang dihapuskan (Pasal 5 ayat 3a Undang-Undang Darurat Nomor 1 Tahun 1951).

\section{Rasio Hukum Putusan Pengadilan Niaga Menghentikan Putusan Pengadilan Negeri yang Menetapkan Eksekusi atas Harta Kekayaan Debitor Pailit}

Dengan adanya putusan pernyataan pailit kepada debitor, maka secara langsung mengakibatkan segala bentuk putusan hakim yang telah dijatuhkan sebelum pernyataan pailit dikeluarkan, dinyatakan tidak dapat dilaksanakan. Hal ini menunjukkan adanya suatu bentuk kompetensi yang dimiliki oleh Pengadilan Niaga untuk menghentikan putusan Pengadilan Negeri yang menetapkan eksekusi atas harta kekayaan debitor pailit, adapun yang menjadi rasio hukum dari pernyataan tersebut adalah sebagai berikut:

\section{a. Adanya pemindahan kewenangan mutlak (absolut) dari Pengadilan Umum kepada Pengadilan Niaga}

Sebelum berlakunya Undang-Undang Kepailitan, kewenangan absolut untuk menerima, memeriksa dan mengadili perkara kepailitan ada pada Peradilan Umum, namun semenjak berlakunya Undang-Undang Kepailitan Nomor 4 Tahun 1998 telah memindahkan kewenangan mutlak atau absolut dari Pengadilan Umum untuk memeriksa permohonan pailit, dengan menetapkan Pengadilan Niaga sebagai pengadilan yang memiliki kewenangan untuk menerima permohonan kepailitan dan Penundaan Kewajiban Pembayaran Utang (PKPU) sebagaimana tercantum pada ketentuan Pasal 1 angka 7 Undang-Undang Nomor 37 Tahun 2004 dan Penjelasan Pasal 8 Undang-Undang Nomor 8 Tahun 2004 tentang Perubahan Atas Undang-Undang Nomor 2 Tahun 1986 tentang Peradilan Umum. Kemudian dalam ketentuan Pasal 1 angka 5 Undang-Undang Nomor 49 Tahun 2009 tentang perubahan Kedua Atas Undang-Undang Nomor 2 Tahun 1986 tentang Peradilan Umum menyatakan bahwa Pengadilan Khusus adalah pengadilan yang mempunyai kewenangan untuk memeriksa, mengadili dan memutus perkara tertentu yang hanya dapat dibentuk dalam salah satu lingkungan badan peradilan yang berada di bawah Mahkamah Agung yang diatur dalam undang-undang. Kemudian dalam penjelasan Pasal 8 ayat 1 Undang-Undang Nomor 49 Tahun 2009 menyatakan bahwa Yang dimaksud dengan "diadakan pengkhususan pengadilan" ialah adanya diferensiasi/spesialisasi di lingkungan peradilan umum dimana dapat dibentuk pengadilan khusus, misalnya Pengadilan Anak, Pengadilan Niaga, Pengadilan Hak Asasi Manusia,Pengadilan Tindak Pidana Korupsi, Pengadilan Hubungan Industrial, Pengadilan Perikanan yang berada di lingkungan peradilan umum. Konsekuensinya, bahwa suatu pengadilan tidak dapat memeriksa gugatan atau permohonan yang diajukan kepadanya 
apabila secara formil gugatan tersebut masuk ke dalam ruang lingkup kewenangan mutlak pengadilan lain. ${ }^{22}$

Pembentukan Pengadilan Niaga sebagai pengadilan khusus dalam konteks doktrin penyelesaian sengketa bidang hukum privat paling tidak telah membawa perubahan dalam mekanisme penyelesaian sengketa. Setidaknya terdapat dua faktor pengubah mekanisme penyelesaian sengketa pada Pengadilan Negeri oleh Pengadilan Niaga.

Pertama, penyelesaian perkara di Pengadilan Niaga ditetapkan dengan cepat (yakni ditentukan jangka waktunya), sedangkan penyelesaian sengketa di Pengadilan Negeri sama sekali tidak ditentukan jangka waktunya.

Kedua, sifat penyelesaian sengketa pada Pengadilan Niaga ditetapkan harus efektif $^{23}$. Maksudnya, putusan perkara permohonan kepailitan bersifat serta merta. Artinya, putusan Pengadilan Niaga dapat dilaksanakan terlebih dahulu meski terhadap putusan tersebut dilakukan upaya hukum kasasi maupun peninjauan kembali ${ }^{24}$

Pengadilan Niaga merupakan chamber dari Pengadilan Umum ${ }^{25}$, Oleh karena Pengadilan Niaga berada dalam lingkungan Pengadilan Umum, mengakibatkan tidak ada jabatan pada ketua Pengadilan Niaga, karena ketua Pengadilan Negeri juga membawahi ketua Pengadilan Niaga.

Adanya pemindahan kewenangan absolut dari Pengadilan Umum kepada Pengadilan Niaga menunjukkan adanya perubahan kewenangan dalam hal memeriksa dan mengadili antar badan peradilan, selain itu juga adanya faktor dikarenakan Pengadilan Niaga merupakan pengadilan khusus yang berada di bawah Pengadilan Umum yang diberi kewenangan untuk memeriksa dan memutus permohonan pernyataan pailit dan Penundaan Kewajiban Pembayaran Utang. Selain itu, menurut Pasal 300 ayat (1) Undang-Undang Nomor 37 Tahun 2004, Pengadilan Niaga juga berwenang pula memeriksa dan memutus perkara lain di bidang perniagaan yang penetapannya dilakukan dengan undang-undang. Perkara lain di bidang perniagaan ini misalnya, tentang gugatan pembatalan paten dan gugatan penghapusan pendaftaran merek. Kedua hal tersebut masuk ke dalam bidang perniagaan dan diatur pula dalam undang-undang yaitu UndangUndang Nomor 14 Tahun 2001 tentang Paten dan Undang-Undang Nomor 15 Tahun 2001 tentang Merek. Dengan kompetensi absolut ini maka hanya Pengadilan Niaga sebagai satu-satunya badan peradilan yang berhak memeriksa dan memutus perkaraperkara tersebut.

\section{b. Pengadilan Niaga merupakan peradilan khusus yang menyelesaikan masalah kepailitan secara umum}

Berdasarkan Penjelasan Pasal 15 ayat 1 Undang-Undang Nomor 4 Tahun 2004 menjelaskan mengenai yang dimaksud dengan pengadilan khusus:

${ }^{22}$ Sunarmi, Hukum Kepailitan Edisi 2, (Jakarta: PT.Sofmedia, 2010), hlm.230.

23 Elijana S, Pengadilan Niaga, Pelaksanaan dan Dampaknya, Kertas Kerja pada Lokakarya tentang Undang-Undang Kepailitan, (Jakarta:Pusat Pengkajian Hukum, 1998), hlm.8.

${ }^{24}$ Paulus Effendi Lotulung, Putusan atas Permohonan Pernyataan Pailit dan Prosedurnya, Kertas Kerja pada Lokakarya tentang Undang-Undang Kepailitan, (Jakarta: Pusat Pengkajian Hukum, Jakarta, 1998), hlm.3.

${ }^{25}$ Munir Fuady, Hukum Pailit dalam Teori dan Praktek, (Jakarta, 1998), hlm.147. 
Yang dimaksud dengan "pengadilan khusus" dalam ketentuan ini, antara lain, adalah Pengadilan Anak, Pengadilan Niaga, Pengadilan Hak Asasi Manusia, Pengadilan Tindak Pidana Korupsi, Pengadilan Hubungan Industrial yang berada di lingkungan Peradilan Umum, dan Pengadilan Pajak di lingkungan Peradilan Tata Usaha Negara.

Secara sekilas memang terlihat bahwa terdapat setidaknya dua persamaan lainnya yang menghubungkan antara pengadilan-pengadilan "khusus", yaitu adanya hakim khusus dan kompentensi khusus. Persamaan ini sebenarnya tidak terdapat pada semua pengadilan sebagaimana diatur dalam Pasal 15. Pengadilan yang dalam undangundanganya diatur adanya hakim khusus baik berupa hakim ad hoc maupun hakim karir yang memiliki kualifikasi khusus, hanya terdapat pada Pengadilan Anak, Pengadilan Niaga, Pengadilan HAM, Pengadilan Tipikor dan Pengadilan Hubungan Industrial (PHI).

Berdasarkan Penjelasan Pasal 27 ayat 1 Undang-Undang Nomor 48 Tahun 2009 tentang Pokok Kekuasaan Kehakiman menyatakan bahwa pengadilan khusus antara lain Pengadilan Anak, Pengadilan Niaga, Pengadilan Hak Asasi Manusia, Pengadilan Tindak Pidana Korupsi, Pengadilan Hubungan Industrial dan Pengadilan Perikanan yang berada di lingkungan Peradilan Umum, serta pengadilan pajak yang berada di lingkungan Peradilan Tata Usaha Negara.

Peradilan Niaga adalah suatu pengadilan khusus yang berada di lingkungan peradilan umum yang dibentuk dan bertugas menerima, memeriksa, memutuskan permohonan pailit dan penundaan pembayaran utang yang penempatannya dilakukan berdasarkan Peraturan Pemerintah. Pembentukkan Pengadilan Niaga ini merupakan langkah diferensial atas Peradilan Umum, yang dibolehkan pembentukkannya berdasarkan Undang-Undang yang berlaku pada saat itu yaitu Undang-Undang Nomor 14 Tahun 1970 tentang Pokok-Pokok Kekuasaan Kehakiman dan Undang-Undang Nomor 48 Tahun 2009 tentang Pokok Kekuasaan Kehakiman. Dalam kedua Undang-Undang tersebut, Peradilan Khusus yang disebut adalah Pengadilan Niaga tersebut akan khusus bertugas menangani permintaan pernyataan pailit. Selanjutnya pada ketentuan Pasal 8 ayat 1 Undang-Undang Nomor 49 Tahun 2009 tentang Perubahan kedua atas UndangUndang Nomor 2 Tahun 1986 tentang Peradilan Umum menyatakan bahwa lingkungan Peradilan Umum dapat dibentuk Pengadilan Khusus yang diatur dengan undang-undang.

c. Putusan pernyataan pailit oleh Pengadian Niaga mengakibatkan semua keputusan hakim di Pengadilan Negeri yang menyangkut bagian dari harta pailit harus segera dihentikan pelaksanaannya

Pernyataan tersebut diperkuat oleh ketentuan Pasal 32 ayat 1 jo Pasal 31 Undang-Undang Nomor 37 Tahun 2004 yang menyatakan bahwa dengan dikeluarkannya pernyataan pailit, maka semua keputusan hakim yang telah dijatuhkan sebelum pernyataan pailit dikeluarkan, sepanjang menyangkut bagian dari harta pailit harus segera dihentikan pelaksanaannya, dan terhitung semenjak saat itu pula setiap putusan yang berakibat dikenakannya hukuman paksaan badan kepada debitor pailit, harus dinyatakan tidak dapat dilaksanakan.

Hal ini menimbulkan konsekuensi bahwa segala keputusan mengenai penyitaan, baik yang sudah maupun yang belum dilaksanakan, dibatalkan demi hukum, dan jika dianggap perlu maka hakim pengawas berhak menegaskan hal tersebut dengan 
memerintahkan melaksanakan pencocokkan piutang tersebut, dan debitor yang sedang dipenjara harus dilepaskan secara seketika setelah putusan pailit memperoleh kekutan mengikat. Ketentuan pasal ini menunjukkan adanya kompetensi yang dimiliki oleh Pengadilan Niaga untuk menghentikan proses eksekusi di Pengadilan Negeri.

Pelaksanaan putusan hakim dihentikan juga tidak berlaku dilaksanakannya hukuman penjara (paksaan badan) apabila debitor pailit sedang menjalankan hukuman penjara, maka ia harus segera dikeluarkan dari penjara begitu putusan pernyataan pailit mempunyai kekuatan hukum pasti hal ini sebagaimana diatur dalam ketentuan Pasal 31 ayat 3 Undang-Undang Nomor 37 Tahun 2004 tentang Kepailitan dan PKPU.

Dalam perkara perdata dikenal adanya putusan yang memasukkan sanksi terhadap tidak dilaksanakannya putusan yang berupa uang paksa (dwangsom), akan tetapi dalam kepailitan hal tersebut tidak dikenal. Hal ini dikarenakan debitor yang telah dinyatakan pailit oleh Pengadilan Niaga harus dibebankan lagi untuk membayar uang paksa maka akan menjadi beban atas harta pailit yang mengakibatkan boedel pailit menjadi semakin berkurang dan nantinya akan mengurangi porsi yang diterima oleh kreditor. ${ }^{26}$

\section{d. Adanya perbedaan kedudukan hukum dan wewenang antara Pengadilan Niaga dan Pengadilan Negeri}

Pengadilan Negeri bertugas dan berwenang memeriksa, memutus dan menyelesaikan perkara perdata dan pidana ditingkat pertama yang terjadi di wilayah hukumnya. Pengadilan Negeri mengadili menurut hukum dengan tidak membedakan orang. Selain dari Pengadilan Negeri, masih ada jenis pengadilan yang memeriksa dan memutus perkara perdata pada tingkat pertama, yaitu Pengadilan Niaga sebagai pengadilan khusus. Pengadilan Niaga ini berkantor pada Pengadilan Negeri, memeriksa dan memutus perkara kepailitan serta perkara mengenai Hak Kekayaan Intelektual (HAKI).

\section{e. Syarat adanya dua kreditor atau lebih (Concursus Creditorium) untuk melakukan eksekusi di Pengadilan Niaga}

Berdasarkan ketentuan Pasal 2 ayat 1 Undang-Undang Kepailitan Nomor 37 Tahun 2004 tentang Kepailitan dan PKPU, menyatakan bahwa salah satu syarat yang harus dipenuhi untuk menyatakan debitor pailit yaitu debitor harus mempunyai dua kreditor atau lebih. Dengan demikian, Undang-Undang hanya memungkinkan seorang debitor dinyatakan pailit apabila debitor memiliki paling sedikit dua kreditor. Jika debitor hanya mempunyai satu kreditor, maka seluruh harta kekayaan debitor otomatis menjadi jaminan atas pelunasan utang debitor tersebut dengan demikian tidak diperlukan lagi pembagian secara pro rata dan pari passu. Dengan demikian, jelas bahwa debitor tidak dapat dituntut pailit, jika debitor tersebut hanya mempunyai satu kreditor, sedangkan pada Pengadilan Negeri dapat dilakukan eksekusi cukup dengan satu kreditor saja. Oleh sebab itu, apabila pada saat bersamaan terjadi kepailitan dan gugatan terhadap debitor pailit, maka kreditor pada Pengadilan Negeri harus turut serta menjadi kreditor pada Pengadilan

26 Edward Manik, Cara Mudah Memahami Proses Kepailitan dan Penundaan Kewajiban Pembayaran Utang: Dilengkapi Studi Kasus Kepailitan, (Bandung: CV. Mandar Maju, 2012), hlm.117. 
Niaga supaya mendapatkan pelunasan utang. Dalam hal kedudukan masing-masing debitor dalam memperoleh pelunasan utang tergantung dari jenis piutang yang diputuskan oleh Pengadilan Niaga.

Mengenai gugatan yang menyangkut hak dan kewajiban menyangkut harta kekayaan debitor pailit, harus diajukan terhadap kuratornya. Apabila gugatan hukum yang diajukan atau dilanjutkan terhadap debitor pailit, maka penghukuman itu tidak mempunyai kekuatan hukum terhadap harta kakayaan yang dimasukkan kedalam pernyataan pailit tersebut. Hal ini juga berlaku terhadap semua gugatan hukum untuk memenuhi perikatan dari harta pailit selama kepailitan, walaupun diajukan kepada debitor pailit sendiri hanya dapat diajukan dengan laporan untuk pencocokkannya, hal ini sebagaimana tercantum dalam ketentuan Pasal 25 jo Pasal 27 Undang-Undang Kepailitan Nomor 37 Tahun 2004 tentang Kepailitan dan PKPU.

Adapun penjelasan secara ringkas mengenai rasio hukum putusan Pengadilan Niaga menghentikan putusan Pengadilan Negeri yang menetapkan eksekusi atas harta kekayaan debitor pailit, dapat dicermati pada skema berikut ini:

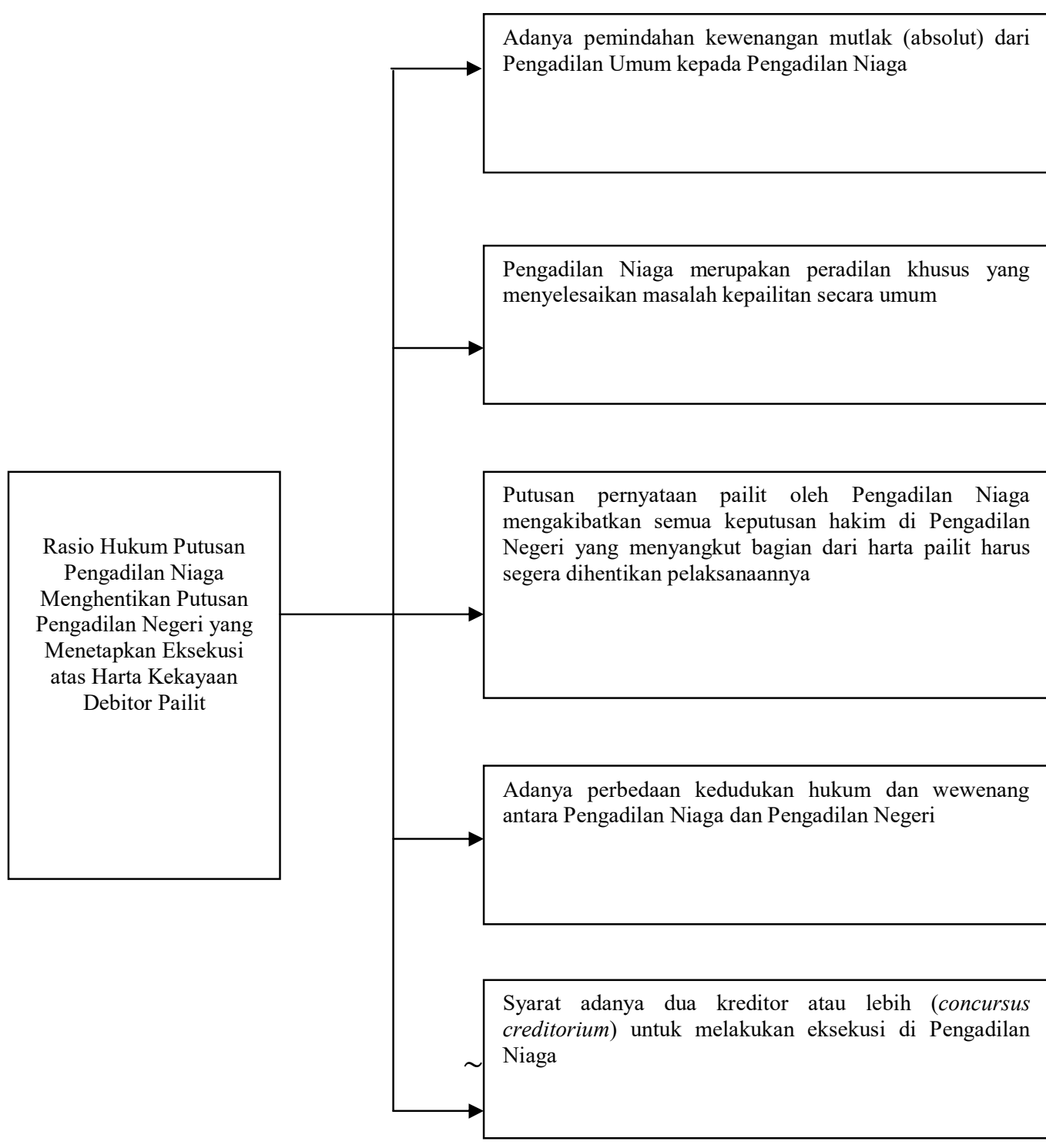




\section{Penutup}

\section{Kesimpulan}

Berdasarkan pada ketentuan Undang-undang Nomor 4 Tahun 1998 tentang Peraturan Pemerintah Pengganti Undang-Undang Nomor 1 Tahun 1998 tentang UndangUndang Kepailitan maka, dibentuklah Pengadilan Niaga yang berwenang untuk memeriksa dan memutuskan tentang persengketaan niaga khususnya pada kepailitan dan HaKI. Salah satu pertimbangan dibentuknya Pengadilan Niaga adalah agar mekanisme penyelesaian perkara permohonan kepailitan dan penundaan kewajiban pembayaran utang, penyelesaiannya dapat dilakukan dengan cepat dan efektif. Adapun wewenang dari Pengadilan Niaga adalah: (1) Memeriksa dan memutusakan permohonan pernyataan pailit; (2) Memeriksa dan memutus permohonan Penundaan Kewajiban Pembayaran Utang; dan (3) Memeriksa perkara lain di bidang perniagaan yang penetapannya ditetapkan dengan undang-undang, misalnya sengketa di kepailitan.

Rasio hukum putusan Pengadilan Niaga yang menyatakan debitor pailit menghentikan putusan Pengadilan Negeri yang menetapkan eksekusi atas harta kekayaan debitor pailit adalah:

a. Adanya pemindahan kewenangan mutlak (absolut) dari Pengadilan Umum kepada Pengadilan Niaga

b. Pengadilan Niaga merupakan peradilan khusus yang menyelesaikan masalah kepailitan secara umum

c. Putusan pernyataan pailit oleh Pengadian Niaga mengakibatkan semua keputusan hakim di Pengadilan Negeri yang menyangkut bagian dari harta pailit harus segera dihentikan pelaksanaannya

d. Adanya perbedaan kedudukan hukum dan wewenang antara Pengadilan Niaga dan Pengadilan Negeri

e. Syarat adanya dua kreditor atau lebih (Concursus Creditorium) untuk melakukan eksekusi di Pengadilan Niaga.

\section{Saran}

Dalam rangka pengembangan kompetensi atau wewenang Pengadilan Niaga di era globalisasi, maka diperlukan konsep yang matang untuk mempersiapkan perluasan kompetensi absolut dari Pengadilan Niaga agar Pengadilan Niaga dapat dipercaya dan kredibel di mata pencari keadilan, selain itu pula diperlukam pengakuan atas keberadaan dan eksistensi Pengadilan Niaga dalam hubungannya dengan wewenang yang dimiliki Pengadilan Niaga dalam memeriksa dan memutus permohonan pernyataan pailit melalui adanya pengaturan mengenai kekhususan hukum acara Pengadilan Niaga, dikarenakan hukum acara yang selama ini digunakan dalam pemeriksaan perkara kepailitan di Pengadilan Niaga masih menggunakan ketentuan Herziene Indonesisch Reglement atau Rechreglement Buitengewesten (HIR/R.BG).

Untuk memberikan perlindungan hukum yang memadai kepada pihak ketiga (penggugat), yang perkara perdatanya dimenangkan di Pengadilan Negeri perlu dibuat 
mekanisme hukum acara tentang penghentian eksekusi putusan Pengadilan Negeri sehubungan dengan adanya putusan Pengadilan Niaga yang menyatakan debitor pailit.

\section{Daftar Pustaka}

\section{Buku}

Asikin, Zainal, Hukum Kepailitan dan Penundaan Kewajiban Pembayaran Utang di Indonesia, Bandung: Pustaka Reka Cipta, 2013.

Efendi, Jonaedi dan Johny Ibrahim,Metode Penelitian Hukum Normatif dan Empiris,Cetakan Kedua, Depok:PrenadaMedia Group, 2018.

Fuady, Munir, Hukum Pailit Dalam Teori dan Praktek, Edisi Revisi (disesuaikan dengan Undang-undang Nomor 37 Tahun 2004), PT.Citra Aditya Bakti, Bandung, 2005.

Hartini, Sri Redjeki, Hukum Kepailitan, Malang: Universitas Muhamadiyah Malang Press, 2008.

Hartini, Rahayu, Hukum Kepailitan, Malang: Universitas Muhamadiyah Malang, 2008.

Harahap, M. Yahya, Hukum Acara Perdata Tentang Gugatan, Persidangan, Penyitaan, Pembuktian, dan Putusan Pengadilan, Jakarta: Sinar Grafika, 2005.

Jono, Hukum Kepailitan, Jakarta: Sinar Grafika, 2008.

Manik, Edward, Cara Mudah Memahami Proses Kepailitan dan Penundaan Kewajiban Pembayaran Utang: Dilengkapi Studi Kasus Kepailitan,Bandung: CV. Mandar Maju, 2012..

Puang, Victorianus M.H. Randa, Penerapan Asas Pembuktian Sederhana dalam Penjatuhan Putusan Pailit, Jakarta: PT.Sarana Tutorial Nurani Sejahtera (SATU NUSA), 2011.

Rusli,Hardijan Rusli,Metode Penelitian Hukum Normatif:Bagaimana?, Law Review Fakultas Hukum Universitas Pelita Harapan, Volume V No.3 Tahun 2006.

Salim HS dan Erlies Septiana Nurbani, Penerapan Teori Hukum Pada Penelitian Tesis dan Disertasi, Jakarta: PT. RajaGrafindo Persada, 2013.

Sunarmi, Hukum Kepailitan Edisi 2, Jakarta: PT.Sofmedia, 2010.

Soekanto, Soerjono, dan Sri Mamudji, Penelitian Hukum Suatu Tinjauan Singkat,Jakarta: PT RajaGrafindo Persada,2001.

Soekanto,Soerjono, Pengantar Penelitian Hukum, Cetakan III, (Jakarta: UI-Press, 2008.

Yahanan, Annalisa, Kepailitan dan Penundaan Kewajiban Pembayaran Utang, Universitas Sriwijaya, Palembang, 2007. 


\section{Disertasi, Jurnal Ilmiah, Makalah, dan Kamus}

Elijana S, Pengadilan Niaga, Pelaksanaan dan Dampaknya, Kertas Kerja pada Lokakarya tentang Undang-Undang Kepailitan, Jakarta:Pusat Pengkajian Hukum, 1998.

E. Utrecht, dalam KN. Sofyan Hasan, Sertifikasi Halal Produk Pangan Dalam Hukum Positif Di Indonesia (Sebagai Implementasi Perlindungan Jaminan Kepastian Hukum terhadap Warga Negara), Disertasi, Palembang: Program Doktor Ilmu Hukum Fakultas Hukum Universitas Sriwijaya, 2014.

Lotulung, Paulus Effendi, Putusan atas Permohonan Pernyataan Pailit dan Prosedurnya, Kertas Kerja pada Lokakarya tentang Undang-Undang Kepailitan, Jakarta: Pusat Pengkajian Hukum, Jakarta, 1998.

Wignjosumarto, Parwoto, Hukum Kepailitan Selayang Pandang “ Himpunan Makalah”, Jakarta: PT. Tata Nusa, 2003.

\section{Internet}

Asep Iwan Iriawan, Kewenangan Pengadilan Niaga Tidak Jelas, http: //www. Maxblogpress. com/ plugins/ msa/, Berita, diakses pada 7 Desember 2014.

Kewenangan Pengadilan Niaga dalam Mengadili Perkara Kepailitan, http:/ www. Journalonlines .Info/, diakases pada 3 Desember 2014.

\section{Peraturan Perundang-Undangan}

Kitab Undang-Undang Hukum Perdata

Undang-Undang Nomor 4 Tahun 1998 tentang Penetapan Pemerintah Pengganti UndangUndang

Undang-Undang Nomor 14 Tahun 1970 tentang Ketentuan Pokok Kekuasaan Kehakiman

Undang-Undang Nomor 2 Tahun 1986 tentang Peradilan Umum

Undang-Undang Nomor 4 Tahun 2004 tentang Ketentuan Pokok Kekuasaan Kehakiman

Undang-Undang Nomor 8 Tahun 2004 tentang Peradilan Umum

Undang-Undang Nomor 37 Tahun 2004 Tentang Kepailitan dan Penundaan Kewajiban Pembayaran Utang

Peraturan Pemerintah Pengganti Undang-Undang Nomor 1 Tahun 1998 tentang Perubahan atas Undang-Undang tentang Kepailitan

Keputusan Presiden Nomor 97 Tahun 1999 Tentang Pembentukkan Pengadilan Niaga pada Pengadilan Negeri 